\title{
Nowa fala fanatyzmu w nauce *
}

Gdy tylko biolodzy ewolucyjni przywykli do ataków kreacjonistów biblijnych, zaczął nas żądlić nowy gatunek osy: akademicki antyewolucjonista. W przeciwieństwie do naszych starych wrogów, krytycy ci - w osobach Davida Berlinskiego, Phillipa Johnsona i Michaela Behe'ego - mają solidne wykształcenie akademickie, a jeśli ich poglądy są zakorzenione w religii, zatrzymują je dla siebie. Kilka cech mają oni jednak wspólnych z religijnymi kreacjonistami. Obie grupy nie są wyszkolone w biologii ewolucyjnej, nie publikują swoich tekstów w profesjonalnej literaturze naukowej i postrzegają nas, ewolucjonistów, jako nękanych dużymi kłopotami, gorliwie strzegących zleżałego darwinizmu, w który potajemnie niedowierzamy. Ponadto, tak jak Behe'ego „argument ze złożoności”, wiele antyewolucjonistycznych argumentów jest identycznych z argumentami kreacjonistów biblijnych i zaledwie trochę zmienionych, aby zaakceptowała je społeczność akademicka. (Pouczające będzie, na przykład, porównanie stosunku Phillipa Johnsona do zapisu kopalnego w Sądzie nad Darwinem ze stosunkiem Duane'a Gisha w Evolution: The Fossils Say No!). ${ }^{1}$

\footnotetext{
* Jerry A. Coyne, „More Crank Science”, Boston Review, luty/marzec 1997, http://www. bostonreview.net/br22.1/coyne.html. Z języka angielskiego za zgodą Autora przełożył Dariusz Sagan. Recenzent: Grzegorz NowaK, Zakład Biochemii UMCS, Lublin.

${ }^{1}$ Phillip Johnson, Darwin on Trial, Regnery Gateway, Washington, DC 1991 [thum. pol.: Phillip E. Johnson, Sąd nad Darwinem, przełożył Robert Piotrowski, Oficyna Wydawnicza „Vocatio”, Warszawa 1997]; Duane T. Gish, Evolution: The Fossils Say No!, 3rd ed., Creation-Life Publishers, San Diego 1979.
} 
Behe jest szczególnie wpływowy, ponieważ jest prawdziwym biochemikiem. Znakomita krytyka Darwin's Black Box, autorstwa Allena Orra, pokazuje jednak, że centralny argument Behe'ego na rzecz „nieredukowalnej złożoności” ma głębokie wady. Chociaż Orr używa naukowej amunicji, by obalić ten argument, nie należy zakładać, iż Darwin's Black Box jest poważnym dziełem naukowym. Książka ta posiada wiele cech „fanatycznej nauki”, tego skrajnego jej gatunku, w skład którego wchodzi homeopatia, teoria spolimeryzowanej wody i poszukiwanie zimnej syntezy:

1. Behe rozmyślnie nie przedstawił bezpośrednio swoich poglądów społeczności naukowej. Nie opublikował lub (o ile wiem) nie spróbował opublikować swojej krytyki darwinizmu w profesjonalnej literaturze, ani nie ubiegał się o pomoc ze strony poważanych ewolucjonistów (jego książka nie uwzględnia żadnego z nich). Darwin's Black Box pomija naukowców, aby łatwiej wywrzeć wrażenie kwalifikacjami Behe'ego jako biologa. Książka wspomagana jest przy tym przez wydawcę, który zdaje się dbać bardziej o zysk niż trafność (pamiętajmy, że Free Press, oddział wydawnictwa Simon \& Schuster, wydało także The Bell Curve). Jak wyraźnie pokazał to Orr, wiedza Behe'ego w zakresie biologii ewolucyjnej jest powierzchowna, zdobyta nie na podstawie literatury technicznej, lecz z bardziej popularyzatorskich prac Goulda, Dawkinsa i innych.

2. Jak zauważyłem w swojej własnej recenzji Darwin's Black Box, ${ }^{2}$ Behe’ego teoria złożoności biochemicznej jest nienaukowa, gdyż jest nietestowalna: nie można wyobrazić sobie obserwacji czy eksperymentu, które mogłyby ją obalić. Jego teoria to hybryda - Behe utrzymuje, że niektóre procesy biochemiczne wyewoluowały, podczas gdy inne złożył do kupy niezidentyfikowany Wielki Projektant. Czego nie da się wyjaśnić na gruncie darwinizmu, musi więc podpadać pod inteligentny projekt. Takiej teorii nie można sfalsyfikować, ponieważ za każdym razem, gdy jakiś proces biochemiczny uzyska wyjaśnienie

\footnotetext{
${ }^{2}$ J.A. Coyne, „God in the Details”, Nature 1996, vol. 383, s. 227-228.
} 
ewolucyjne, Behe łatwo może zawęzić dziedzinę Projektanta do procesów jeszcze niewyjaśnionych.

3. Przy braku reakcji naukowców na jego poglądy, Behe przesadza, mówiąc o ich znaczeniu. Przyrównuje siebie do Newtona, Einsteina i Pasteura, lecz twierdzi, że nieprzychylna mu grupa ewolucjonistów blokuje objęcie przez niego dominacji nad tym panteonem. Deklarowanie się jako niedostrzeżony geniusz jest znakiem rozpoznawczym fanatycznej nauki.

4. W końcu, argumenty Behe'ego, podobnie jak argumenty kreacjonistów biblijnych, są wręcz naszpikowane cytatami zaczerpniętymi od ewolucjonistów. Wiele $\mathrm{z}$ nich wyjęto $\mathrm{z}$ kontekstu, aby sprawić wrażenie, że naszą dziedzinę rozdziera wewnętrzne zwątpienie. To właśnie takie wybiórcze cytowanie sprawia - bardziej niż cokolwiek innego - że Behe jest blisko związany ze swoimi religijnymi poprzednikami.

Sam boleśnie odczułem zamiłowanie Behe’ego do machlojek z cytatami. Na stronie 29 Darwin's Black Box pisze on tak:

Jerry Coyne z Wydziału Ekologii i Ewolucji Uniwersytetu Chicagowskiego wydaje niespodziewany werdykt: „Dochodzimy do wniosku - nieoczekiwanie - że mamy mało świadectw empirycznych przemawiających za poglądem neodarwinowskim: jego podstawy teoretyczne i popierające go świadectwo doświadczalne są słabe".

Jak widać, jestem jednym $\mathrm{z}$ tych bojaźliwych biologów, którzy widzą błędy darwinizmu, ale nie chcą ich uznać. Była to dla mnie nowina. Z pewnością zaliczam się do bardziej ortodoksyjnych ewolucjonistów i z trudnością postrzegam naszą dziedzinę jako przepełnioną wadami. Cytowana wyżej rozprawa (faktycznie napisana przez Allena Orra i przeze mnie) ${ }^{3}$ jest poświęcona technicznej debacie pomiędzy

\footnotetext{
${ }^{3}$ H. Allen OrR and Jerry A. Coyne, „The Genetics of Adaptation: A Reassessment”, The American Naturalist 1992, vol. 140, s. 725-742.
} 
ewolucjonistami: czy adaptacje opierają się na dużej ilości małych mutacji genetycznych (tradycyjny neodarwinizm), kilku dużych mutacjach, czy pewnej mieszance tych dwu? Wyciągnęliśmy wniosek, że choć nie ma dobrego świadectwa empirycznego przemawiającego za pierwszą lub pozostałymi możliwościami, to istnieją jednak wskazówki przemawiające za tym, że duża skuteczność od czasu do czasu może być ważna. Nasza rozprawa nie rzuca nawet cienia wątpliwości na kwestię istnienia ewolucji czy możliwości wyjaśniania adaptacji poprzez dobór naturalny.

Zajrzałem jeszcze raz do tej rozprawy, aby zobaczyć, co Orr i ja tam napisaliśmy. Okazuje się, że w środku naszego zdania Behe umieścił kropkę, której wcześniej tam nie było. Oto pełny cytat, umieszczony w swoim kontekście:

Chociaż kilku biologów zakwestionowało ewolucyjną rolę mutacji czy dużej skuteczności (Gould 1980; Maynard Smith 1983; Gottlieb 1984; Turner 1985), to neodarwinizm odniósł duże zwycięstwo, a mało uwagi poświęca się genetycznej podstawie adaptacji. Rzeczywiście, sprawę tę uważa się za martwą od tak dawna, że niewielu może znać świadectwo empiryczne odpowiedzialne za jej upadek.

Tutaj rozpatrujemy to świadectwo. Dochodzimy do wniosku - nieoczekiwanie że mamy mało świadectw empirycznych przemawiających za poglądem neodarwinowskim: jego podstawy teoretyczne i popierające go świadectwo doświadczalne są słabe i nie ma żadnych wątpliwości, że mutacje o dużej skuteczności są czasem ważne w adaptacji. Musimy jednak pośpiesznie dodać, że nie jesteśmy „makromutacjonistami”, którzy uważają, że adaptacje prawie zawsze dotyczą ważnych genów. Neodarwiniści mogą mieć rację. Jest jednak prawie na pewno prawdą, że niektóre adaptacje obejmują wiele genów o małej skuteczności, a inne - ważne geny. Nasze pytanie brzmi: jak często adaptacja dotyczy ważnego genu? Mamy nadzieję, iż zachęcimy ewolucjonistów do ponownego zbadania tej zaniedbanej kwestii i dostarczenia świadectwa empirycznego, które by ją rozstrzygnęło.

Umieszczając ową kropkę (i oddzielając to zdanie od zdań z nim sąsiadujących), Behe zmienił znaczenie tego fragmentu. Dyskusja na 
temat jednego aspektu darwinizmu - względnej wielkości mutacji adaptacyjnych - stała się nagle krytyką całego darwinowskiego przedsięwzięcia. To nie jest niedbałe uprawianie nauki, lecz umyślne przeinaczenie.

Być może przesadnie to roztrząsam, ale wiadomo, że kreacjoniści, rozpatrując szczegółowe dane, odwołują się do Boga. Czy można zaufać komuś, kto przerabia cytaty, że bezstronnie i obiektywnie analizuje dane naukowe?

Autorem jednej z notatek wydawniczych na okładce Darwin's Black Box jest Peter Van Inwagen, profesor filozofii w Notre Dame (Behe miał najwyraźniej kłopot w znalezieniu biologów, którzy udzieliliby poparcia jego książce): „Jeśli darwiniści zignorują tę ważną książkę, błędnie ją zinterpretują lub ośmieszą, będzie to świadectwo na rzecz powszechnego podejrzenia, że darwinizm funkcjonuje dzisiaj bardziej jako ideologia niż teoria naukowa. Jeśli skutecznie odpowiedzą na argumenty Behe'ego, będzie to przemawiać na rzecz darwinizmu".

Udzielono odpowiedzi Behe'emu. Czy możemy teraz oczekiwać, że odrzuci on swoje poglądy? Nie spodziewałbym się tego. 